\title{
PARAPLEGIA FOLLOWING SURGERY IN FOIX AND ALAJOUANINE SYNDROME
}

\author{
(Arteriovenous Malformation of the Spinal Cord)
}

\author{
By Lawrence W. Kneisley, M.D. *, Manuel Rivera Dominguez, M.D., \\ Amico Bignami, M.D. and Alain B. Rossier, M.D. \\ From the Spinal Cord Injury Service, West Roxbury Veterans Administration Medical \\ Center, and the Departments of Neurology, Neuropathology, and Orthopedic Surgery, \\ Harvard Medical School, Boston, Mass.
}

\begin{abstract}
Two patients with spinal cord arteriovenous malformation became paraplegic after removal of the abnormal vessels from the dorsal surface of the thoracolumbar spinal cord. Surgical exposure of a spinal cord arteriovenous malformation without an attempt at removal accelerated the pace of progressive paraparesis in two other patients. The poor outcome of our cases is, however, not representative of modern surgical techniques, since selective spinal angiography and the operating microscope were not used.

We propose that the intramedullary vascular changes in this condition are an integral component of the arteriovenous malformation. Additionally, the phenomenon of nocturnal seminal ejaculation in spite of progressing impotence may be a clinical feature unique to spinal cord arteriovenous malformations.
\end{abstract}

Key words: Foix-Alajouanine disease; Arteriovenous malformations; Impotence; Nocturnal ejaculations.

SINCE the introduction of selective spinal angiography in the diagnosis of spinal cord arteriovenous malformations, there has been increased interest in the condition 'Myélite nécrotique subaiguë' (Foix and Alajouanine, 1926). The early cases of spinal arteriovenous malformation were reported as clinical observations without autopsy findings and the similarity of the two conditions was not recognised. Since that time, it has been shown that the spinal cords of patients with spinal arteriovenous malformations also display the intramedullary changes characteristic of Foix and Alajouanine disease (Hughes, 1976).

The purpose of this paper is to use clinical and pathological observations in one patient to understand the effects of arteriovenous malformation on the spinal cord. The clinical features in four other patients will be reviewed with emphasis upon a possible unique symptom in two of them. The series consists of five male patients ranging in age from 34 to 58, admitted to the Spinal Cord Injury Service at the West Roxbury Veterans Administration Hospital between I95I and 1975. Although the study is retrospective and carries an inherent risk of nonrepresentative sampling, it is not practicable to minimise this risk for such a rare condition.

Address all communications to: Dr A. B. Rossier, Spinal Cord Injury Service, West Roxbury V.A. Medical Center, I400 VFW Parkway, Boston, Mass. 02132.

* Supported by the Veterans Administration. Dr Kneisley is a Veterans Administration Research Associate. 


\section{Report of Cases}

Case I. A 43-year-old man was admitted to another hospital in October 1953, unable to walk. The patient had experienced right leg numbness for 2 years and gradually increasing bilateral leg weakness and sensory loss for 6 months. He noted back pain radiating to the groin and flank 6 weeks before admission, difficulty with penile erections for I month and urinary incontinence in the 3 days before admission. On examination there were no cutaneous haemangiomas; the skin over the right ischium was ulcerated. The patient was hypesthetic and hypalgesic below the LI dermatome but had normal pain sensation over the scrotum. Vibratory sensation was absent in the L4 spinous process and feet and diminished in the legs. Position sense was absent in the toes but preserved above. All the muscles of the lower extremities were extremely weak and there was no motion about the knees and ankles. Knee and ankle jerks were absent; there was no response to plantar stimulation and the anal sphincter tone was diminished.

A myelogram showed a patchy, irregular filling defect suggesting a spinal cord tumour from the I Ith thoracic to the first lumbar vertebral levels which partially blocked the subarachnoid space at the I2th thoracic and first lumbar vertebral levels.

\section{Surgical Procedure (Case I)}

The laminae of the 6th through I2th thoracic vertebrae were removed and the dura and arachnoid were opened, disclosing a mass of abnormal vessels that covered the posterior surface of the conus medullaris, lumbar and thoracic cord and extended around the cord to the anterior surface. Some dark-red coloured vessels swelled when occluded with forceps and were presumed to be veins. Brighter red vessels which did not swell when occluded were presumed to be arteries. The malformation appeared primarily on the arachnoid and was only loosely attached to the pia mater. One vessel, $10 \mathrm{~cm}$ long, which ran a tortuous course over posterior, lateral and anterior surfaces of the thoracic, lumbar and sacral cord was removed in one piece. Many other vessels of varying calibre were likewise removed. At the end of this procedure, the dorsal surface of the lumbosacral cord and conus medullaris were 'cleared of any dilated vessels'. A I mm, thinwalled, tortuous vessel on the anterior surface, judged to be the anterior spinal artery, and a $2 \mathrm{~mm}$, dilated, $8 \mathrm{~cm}$ long vessel on the dorsal surface of the lower thoracic cord were left untouched. The dura was left open.

After the surgery the patient had a flaccid, areflexic paraplegia with complete loss of all sensation below the T9 dermatome. He was transferred to the Spinal Cord Injury Service of the West Roxbury Veterans Administration Hospital. His neurological status remained unchanged until his death from atherosclerotic heart disease in 1974 .

\section{Autopsy Findings-Case I}

At autopsy there was marked thickening of the dura mater which extended from the seventh thoracic root to the lumbar enlargement. Caudal to the level of the ninth thoracic root, the thickened dura was adherent to the posterior surface of the cord and the dural sac could be opened only anteriorly. Dilated, tortuous vessels could be seen on the posterior surface of the cord at the level of seventh thoracic root and among the spinal roots of the cauda equina (Fig. I).

In histological sections, there was severe central destruction and cavitation of the spinal cord which extended caudally from the level of the tenth thoracic root. The peripheral white matter, although severely gliotic and almost depleted of nerve fibres, was relatively preserved (Fig. 2). Dilated blood vessels with thick fibrous walls were seen on the dorsal surface of the cord underlying the thickened dura (Fig. 2). Between the levels of the sixth and seventh thoracic roots, rostral to the area of severe destruction, there was a marked increase in vessel number and moderate loss of myelin fibres in the lateral columns (Fig. 3). Many vessels in this area showed thickened walls with hyaline changes (Fig. 4). No vascular changes were observed in the upper thoracic and cervical spinal cord, although a myelin stain showed some pallor of the lateral columns at these levels. 


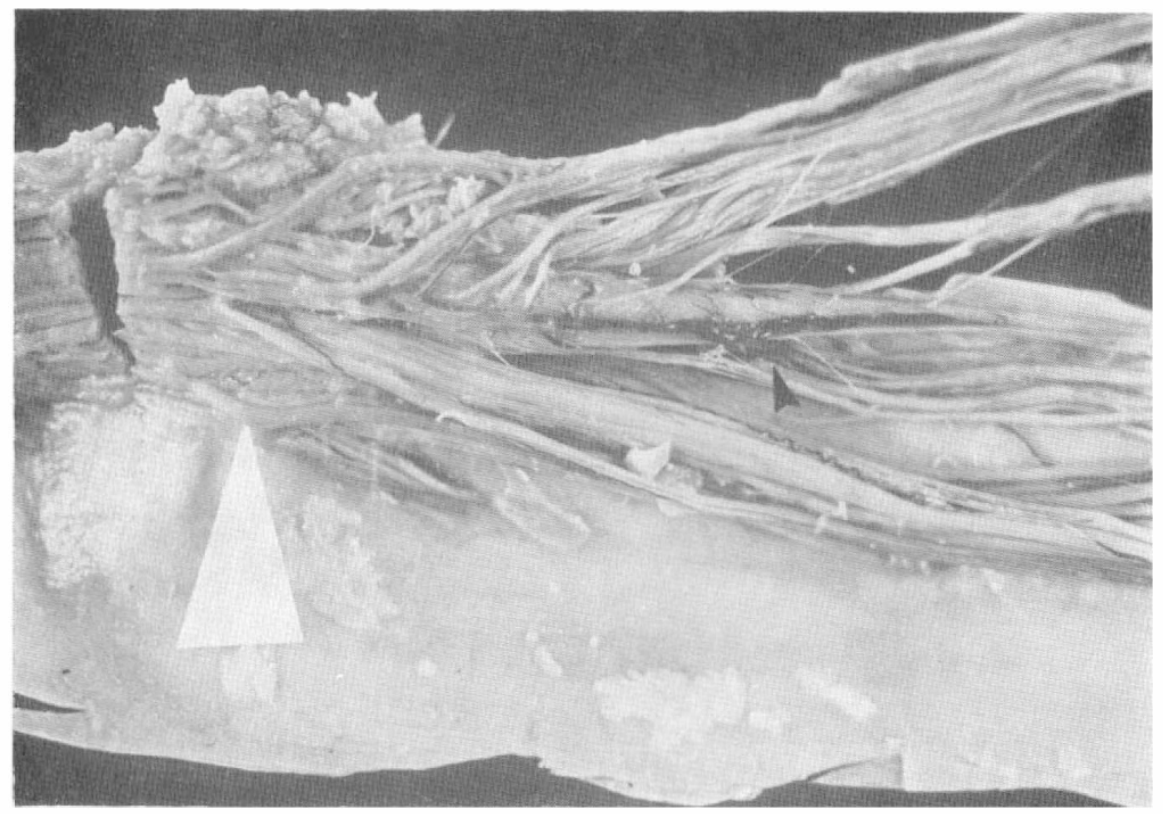

FIG. I

Dilated blood vessels (small black arrow) among the roots of the cauda equina. The large white arrow points to a cross-section of the markedly thickened dura on the opposite margin of the cord.

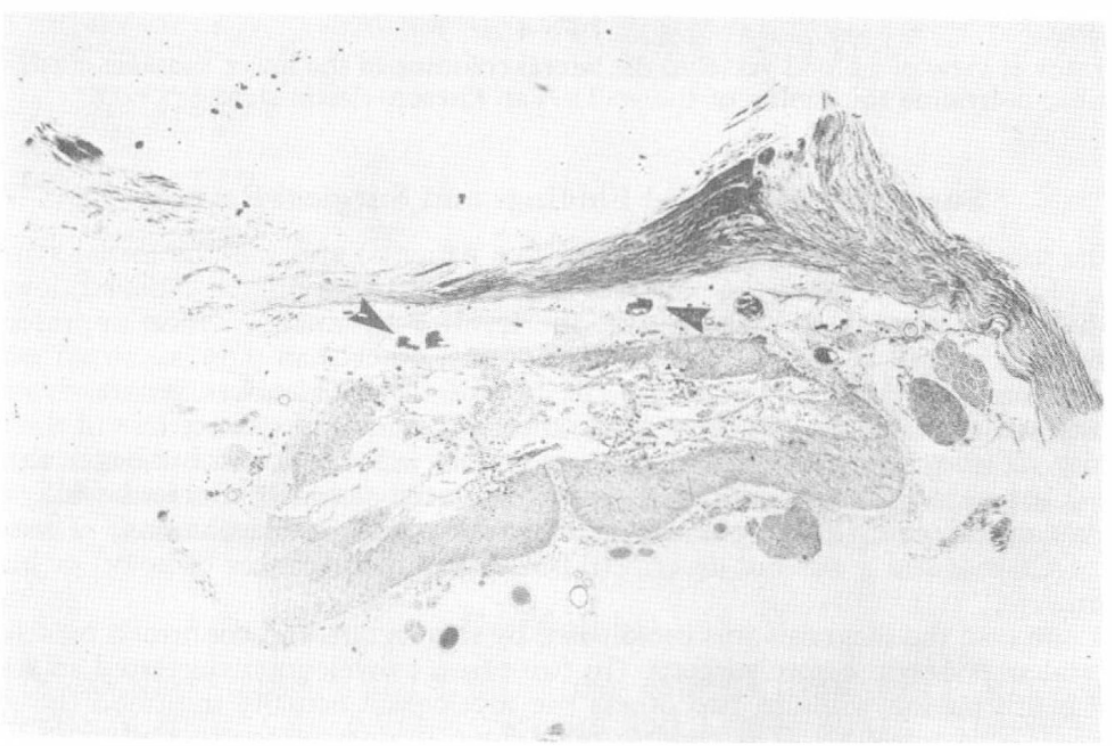

FIG. 2

Severe destruction with central cavitation of the spinal cord at the level of Tio (the lumbar enlargement showed a similar appearance). Note the dilated blood vessels underlying the thickened dura on the dorsal surface of the cord (arrows). Luxol fast blue stain. 

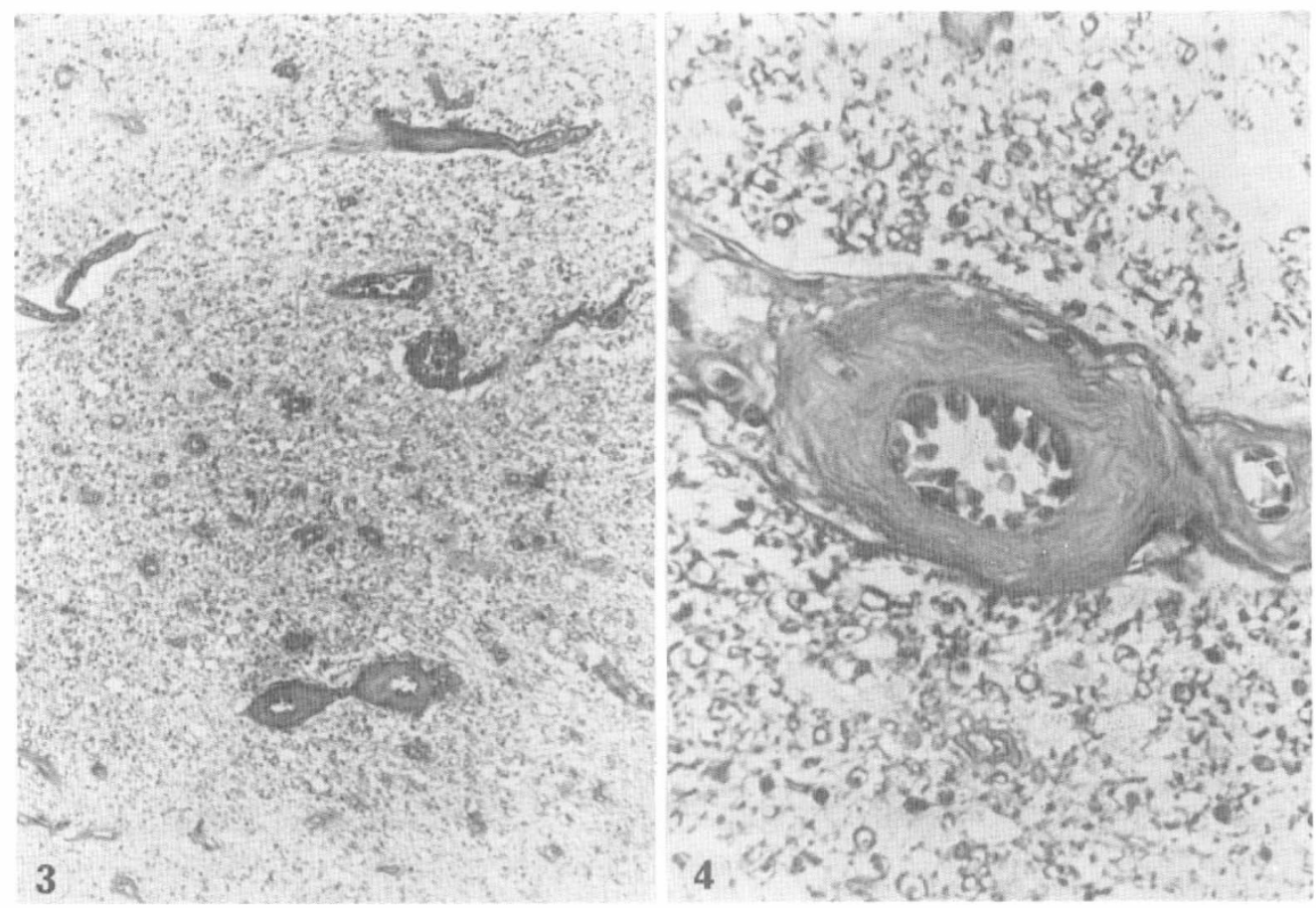

FIG. 3

Appearance of the blood vessels in the lateral columns of the spinal cord at the T9 level. Van Gieson-elastic stain. $\times$ Io0.

FIG. 4

Higher power view of a blood vessel in the lateral columns of the lower thoracic cord. Note the fibrous-hyaline thickening of the wall. Van Gieson-elastic stain. $\times 600$.

\section{Summary of Clinical Findings and Surgical Results}

The most frequent symptom was pain (five patients) and was the initial symptom in two. In both of the latter the pain was sciatic in distribution and radiated down one or both legs. In another, back pain at the level of the malformation appeared immediately after a fall (Case 3). Sensory symptoms, other than pain, occurred early in three patients and eventually in four. In two of these there was progressive lower extremity sensory loss and weakness, while the other had only sensory loss in the lower extremity. The weakness and sensory loss was gradual in four patients but began abruptly in one (Case 4). Two patients noted recent nocturnal seminal emissions while at the same time experiencing flagging ability to achieve erections or ejaculations. The sexual status of Cases 2 and 4 was not described, but all had disturbances of bowel or bladder function.

In one case the diagnosis was established by myelogram and confirmed by selective intercostal arteriogram before surgery. In two cases, a myelogram suggested an arteriovenous malformation while in two others the myelogram actually indicated the wrong diagnosis (Cases I and 3). The cerebrospinal fluid, lumbar puncture, and plain X-rays of the spine were normal in all cases. The malformations were situated at thoracic, lumbar and cauda equina in all cases, and in only one (Case 4) did the myelogram indicate abnormal vessels at the cervical level.

Both patients in whom excision was attempted developed complete or severe sensory 


\section{TABLE I}

Summary of clinical course and outcome in five patients with spinal cord AVM

\begin{tabular}{|c|c|c|c|c|c|}
\hline Case (age/year) & Clinical summary & Radiologic study & $\begin{array}{l}\text { Preoperative } \\
\text { diagnosis }\end{array}$ & $\begin{array}{l}\text { Surgical } \\
\text { findings and } \\
\text { procedure }\end{array}$ & $\begin{array}{l}\text { Postoperative } \\
\text { result }\end{array}$ \\
\hline $\begin{array}{l}\text { I. P. R. (43) } \\
\text { I } 953\end{array}$ & $\begin{array}{l}\text { Progressive lower ex- } \\
\text { tremity sensory loss } \\
\text { (2 years) and motor } \\
\text { weakness (6 months). } \\
\text { Back pain radiating } \\
\text { to groin and flank } \\
\text { (6 weeks) }\end{array}$ & $\begin{array}{l}\text { Myelogram: irregular } \\
\text { defect causing } \\
\text { partial block at } \\
\text { TI2-LI }\end{array}$ & $\begin{array}{l}\text { Spinal cord } \\
\text { tumour }\end{array}$ & A VM removed & $\begin{array}{l}\text { Flaccid complete para- } \\
\text { plegia, T-9 }\end{array}$ \\
\hline $\begin{array}{l}\text { 2. G. L. (38) } \\
\text { I } 972\end{array}$ & $\begin{array}{l}\text { Slowly ascending } \\
\text { sensory loss, } 2 \\
\text { months, flexor } \\
\text { spasms left leg }\end{array}$ & $\begin{array}{l}\text { Myelogram: tortuous } \\
\text { vessels } \mathrm{T}_{3}-\mathrm{T}_{7} \text {. } \\
\text { Selective intercostal } \\
\text { and brachial arterio- } \\
\text { grams: AVM at T4- } \\
\text { T6 supplied by three } \\
\text { vessels from the right } \\
5 \text { th, 6th, 7th and } \\
\text { left } 4 \text { th thoracic } \\
\text { intercostal arteries }\end{array}$ & AVM & AVM removed & $\begin{array}{l}\text { Spastic paraparesis } T_{5} \\
\text { on right, L4 on left. } \\
\text { During ensuing year } \\
\text { moderate improve- } \\
\text { ment; patient walks } \\
\text { with walker and leg } \\
\text { braces }\end{array}$ \\
\hline $\begin{array}{l}\text { 3. J. C. (4I) } \\
\text { I } 957\end{array}$ & $\begin{array}{l}\text { Low back pain radiat- } \\
\text { ing to left leg for } 3 \\
\text { months after a fall. } \\
\text { Nocturnal seminal } \\
\text { emissions with flag- } \\
\text { ging penile erections } \\
\text { and impotence }\end{array}$ & $\begin{array}{l}\text { Myelogram: irregular } \\
\text { defect, } \mathrm{T}_{9}-\mathrm{L}_{\mathrm{I}}\end{array}$ & $\begin{array}{l}\text { Herniated inter- } \\
\text { vertebral disc }\end{array}$ & $\begin{array}{l}\text { Laminectomy } \\
\text { without re- } \\
\text { moval }(\mathrm{X} 2) \\
\text { of AVM }\end{array}$ & $\begin{array}{l}\text { Ist operation: progres- } \\
\text { sive paraparesis. } \\
\text { 2nd operation I } 8 \\
\text { days later: complete } \\
\text { paraplegia, Tro, } \\
\text { with diminished } \\
\text { reflexes }\end{array}$ \\
\hline $\begin{array}{l}\text { 4. R. J. (34) } \\
\text { I95 I }\end{array}$ & $\begin{array}{l}3 \text { years before diag- } \\
\text { nosis-sudden onset } \\
\text { of bilateral leg weak- } \\
\text { ness and numbness, } \\
\text { with persistently un- } \\
\text { steady gait. } 6 \\
\text { months before diag- } \\
\text { nosis-persistent } \\
\text { sciatic and low back } \\
\text { pain }\end{array}$ & $\begin{array}{l}\text { Myelogram: wormlike } \\
\text { densities with partial } \\
\text { block, TI I-LI }\end{array}$ & AVM & $\begin{array}{l}\text { Laminectomy } \\
\text { without re- } \\
\text { moval of } \\
\text { AVM }\end{array}$ & $\begin{array}{l}\text { Worsening of mild } \\
\text { paraparesis. Five } \\
\text { weeks after surgery } \\
\text { sudden onset of } \\
\text { complete Tro para- } \\
\text { plegia after pul- } \\
\text { monary embolus } \\
\text { and transient hypo- } \\
\text { tension. Reflexes } \\
\text { spastic }\end{array}$ \\
\hline $\begin{array}{l}\text { 5. V. M. (58) } \\
\text { I } 975\end{array}$ & $\begin{array}{l}\text { Low back pain I } 973 . \\
\text { Laminectomy and } \\
\text { removal of L4-5 } \\
\text { herniated disc (I } 974) \text {. } \\
\text { Progressive bilateral } \\
\text { lower extremity } \\
\text { spasms with slowly } \\
\text { progressive (Io } \\
\text { months) paraparesis. } \\
\text { Bilateral lower ex- } \\
\text { tremity sensory loss. } \\
\text { Nocturnal seminal } \\
\text { emissions with } \\
\text { diminished penile } \\
\text { erection and impot- } \\
\text { ence }\end{array}$ & Normal myelogram & Possible AVM & $\begin{array}{l}\text { Laminectomy } \\
\text { without re- } \\
\text { moval of } \\
\text { AVM }\end{array}$ & $\begin{array}{l}\text { No worsening of } \\
\text { already severe } \\
\text { spastic paraparesis }\end{array}$ \\
\hline
\end{tabular}

and motor loss immediately after the surgical procedure. Of the three patients whose malformations were not removed, one was virtually paraplegic before the surgery while the other two were worsened after the exploration and deteriorated in the weeks afterward. This deterioration was gradual in one patient (Case 3) and sudden in another, occurring in the setting of cardiovascular collapse from a pulmonary embolus (Case 4).

\section{Discussion}

The clinical symptoms and signs of our patients were typical of those of a large series of spinal cord AVM's (Aminoff and Logue, 1974). The symptoms and signs localisable to the cord and/or cauda equina mimicked compression from tumour or other mass, while the radicular pain often suggested a herniated intervertebral disc.

An interesting and possibly unique symptom in two of our cases was the 
apparent paradox of spontaneous nocturnal ejaculations in spite of flagging erections and impotence during sexual intercourse (Cases 3 and 5). This phenomenon was noted but not discussed by Aminoff and Logue in two of their patients with a spinal arteriovenous malformation (Aminoff \& Logue, 1974). It was a late symptom in our patients, occurring only a few times and always in the 3 or 4 weeks preceding hospitalisation. Neither patient recalled the dream content during which the ejaculation occurred nor did either volunteer this symptom, but acknowledged it only after specific inquiry. This symptom may be more common than previously realised. We postulate that the fluctuating, progressive pathological process, whether congestive or ischaemic, allows release of the ejaculatory reflex normally inhibited at spinal and supraspinal levels. The occurrence of ejaculations at night may be related to the phenomenon of nocturnal penile tumescence (usually without ejaculation) which occurs during the rapid eye movement (REM) stage of sleep of post-pubertal males (Hursch et al., I972). This is the sleep stage associated with dreaming and possibly with ejaculations. This association may account for the vernacular term 'wet dream'. Reflex seminal ejaculation also occurs abruptly during execution by hanging (Hussain \& Tozman, 1978) in which the neural arch of the axis is avulsed from the body and the fracture-dislocation crushes the spinal cord (Schneider et al., 1965). To our knowledge, however, nocturnal ejaculation in the presence of failing erections and impotence has not been reported in any other organic condition, even those which mimic spinal cord AVMs, such as spinal tumours, herniated intervertebral discs or demyelinating disease. As such, it may be a unique symptom of spinal cord vascular malformations. However, because the majority of our and others' patients did not have this feature, it is important to stress that any patient with or without back or radicular pain who develops lower extremity sensory or motor loss should be rapidly investigated to diagnose an arteriovenous malformation or other treatable condition of the spinal cord.

\section{Radiologic Diagnosis and Modes of Treatments}

While a positive contrast myelogram may occasionally be normal, 88 per cent and 82 per cent of two large groups of patients with spinal angiomas had myelograms showing tortuous filling defects similar to those seen in three of our cases (Ommaya et al., 1969; Aminoff \& Logue, 1974). Suspected spinal angiomas should now be properly defined by selective spinal angiography, which permits visualisation of the malformation and its feeding vessels, so that a well-planned surgical approach can be undertaken (Doppman et al., 1969; Djindjian et al., I970). Diagnosis by exploratory laminectomy can be deleterious per se, even when the surgeon attempts only decompression of the spinal cord with no attempt to remove the angioma, as Cases 3 and 4 demonstrate.

Although the response to operation in our cases was further neurological deterioration, it would be unfair to condemn all surgical procedures on the basis of the data presented in this report. Until recently spinal cord AVMs were considered untreatable and few neurosurgeons had a large experience with them. With the operating microscope and selective spinal angiography Logue et al. (1974) have reported improvement in functional capacity in 12 of 14 patients treated by excision of the angioma.

Selective spinal angiography, used in only one of our five patients, has radically modified the scope of neurosurgery. This technique better defines the extent of the pathological process and allows for ligation of the vessels feeding the 
angioma as well as for the removal of the fistulous communication and its enlarged draining veins (Doppman et al., I969; Djindjian et al., I970).

Since as many as 80 per cent of spinal AVM's may be entirely extramedullary and situated on the posterior aspect of the spinal cord, surgical removal is feasible. The artery of Adamkiewicz rarely contributes to the blood supply of angiomas located below the cervical region (Decker et al., I975; Logue, I976). Thus the blood supply to the majority of the spinal cord need not be endangered by ligation of the feeding vessels of the malformation. Logue (1966) emphasizes the importance of the following technical aspects of the surgery of spinal A.V. malformations:

(I) Precise knowledge of the AVM's blood supply by selective spinal angiography is essential. Myelography is inadequate to accomplish this.

(2) Laminectomy should be at a level to correlate with the angiographic abnormality, not the clinical dysfunction. Removal of a minimum of three and maximum of five laminae was required in 16 cases.

(3) Temporary occlusion, during surgery, of the feeding vessel(s). Rapid (less than $5 \mathrm{~min}$ ) reduction in the malformation turgor and a colour change from arterial to venous were associated with the best neurologic function after surgery. Patients with malformations showing marginal loss of turgor and little or no colour change after temporary occlusion at the feeding vessels were followed by a less optimal postoperative neurological result.

(4) Total removal of the angioma to prevent revascularisation. Although the incidence or degree of revascularisation after incomplete removal of spinal angiomas is not known the phenomenon is known to occur in cerebral arteriovenous malformations.

(5) The use of the operating microscope to visualise better the colour and pulsation changes in small vessels.

In recent years embolisation of spinal cord arteriovenous malformations has been used as an alternative to surgical excision. Its use has also been advocated for anteriorly situated AVMs when the blood supply of the spinal cord and the malformation are separate and in cases of extensive arachnoiditis or poor medical condition of the patient (Doppman et al., I97I ; Djindjian et al., I975; Ausman et al., 1977).

\section{Pathological Abnormalities}

The pathogenesis of the severe medullary and vascular changes in the spinal cords of patients with spinal cord arteriovenous malformations is not entirely understood. Thrombosis of the large, abnormal, extramedullary vessels is probably a rare phenomenon (Mair \& Folkerts, 1953) and is not seen in most autopsied cases. Spinal cord compression may have been a factor in our case since the myelogram showed a partial obstruction of the subarachnoid space. While in two other series of patients with arteriovenous malformations, myelograms of 3 of 60 and I of I 8 patients showed myelographic blocks at the level of the malformation (Ommaya et al., I969; Aminoff \& Logue, I974), other causes of clinical deterioration and the observed histological changes must be operant in the remaining, and perhaps all, cases.

The notion that the AVM 'steals' arterial blood from its intramedullary destination has been suggested by several authors (Krayenbühl et al., I969; Djindjian et al., 1970). However, the malformations are infrequently supplied by either the arterior spinal artery, by an aortic branch giving rise to the anterior spinal, except in the cervical region. Additionally, the symptoms of spinal AVM 
are not typical of those of anterior spinal artery territory ischaemia. Surgeons with considerable experience treating this condition note that intramedullary anterial connections with the AVM are not usually conspicuous (Aminoff, 1976). The unfavourable effect of the surgical excision of the abnormal vessels in two of our patients may support the suggestion, however, that in some 20 per cent of cases the extramedullary arteriovenous malformation has an angiographically or pathologically demonstrable intramedullary component which carries an important part of the spinal cord blood flow (Brion et al., 1952; Logue et al., I974).

Aminoff (1976) hypothesises that the malformation and the lateral parts of the spinal cord share a common venous drainage and that the elevated venous pressure in the malformation is transmitted to the veins draining the lateral spinal cord. The diminished arteriovenous pressure gradient reduces intramedullary blood flow, resulting in spinal cord hypoxia or microvascular thrombosis with subsequent ischaemic infarction. In our opinion hypoxia may not be an important factor; slowed intraluminar blood flow due to raised venous pressure may be sufficient to produce the pathological changes seen. The fibrous hyaline thickening and degenerative changes of intramedullary vessel walls, virtually constant findings in spinal cord AVMs, are not a feature of the vascular proliferation characteristically seen in brain tissue subjected to long-standing hypoxia (Brand \& Bignami, 1969). It is more likely that the Foix-Alajouanine abnormalities are the response of thin-walled vessels subjected to long-standing, increased, intraluminar pressure and abnormal blood flow and that the intramedullary vascular changes are an essential component of the malformation. It seems likely that these vascular changes gradually occlude blood vessels and cause the spinal cord necrosis characteristic of the condition. If this be so, then surgical intervention early in the course of progression of symptoms is the most rational therapy.

\section{RÉSUMÉ}

Deux patients avec malformation artério-veineuse médullaire devinrent paraplégique après résection des vaisseaux anormaux à la surface dorsale de la moelle dorso-lombaire. Chez deux autres patients, la seule exposition chirurgicale de la malformation artérioveineuse suffit à accélérer le décours de la paraparésie. Il faut cependant réaliser que l'évolution défavorable de ces quatre cas n'est pas représentative des techniques neurochirurgicales modernes puisque, à cette époque, ni l'angiographie médullaire sélective ni le microscope opératoire ne furent utilisés. Les auteurs suggèrent que les altérations vasculaires intramédullaires propres à cette condition sont partie intégrante des malformations artério-veineuses. Il semble en outre que le phénomène des éjaculations nocturnes, en dépit de l'installation progressive d'impotence, représente une condition unique propre aux malformations artérioveineuses de la moelle épinière.

\section{ZUSAMMENFASSUNG}

Nach Entfernung der an der dorsalen thoracolumbalen Rückenmarksoberflächeliegenden arteriovenösen Missbildungen sind 2 Paraplegiker geworden. In 2 anderen Fällen machte die Eröffnung der Dura die Paraparese progressiv schlimmer, obwohl keine Resektion der vaskulären Missbildungen ausgeführt wurde. In diesen 4 Fällen ist der ungünstige Gang der Operationen auf keine Weise auf die moderne neurochirurgische Technik bezüglich, da weder selektive Rückenmarksangiographie noch operative Mikroscop gebraucht wurden. Die Autoren schlagen vor, dass die intramedullären vaskulären Aenderungen eine kennzeichnende Schilderung der arteriovenösen Missbildungen vorstellen. Zusätzlich stellt die Erscheinung der nächtlichen Ejakulationen vor, trotz progressiver Impotenz, ein klinisches Zeichen auf vaskuläre Rückenmarksmissbildungen. 


\section{REFERENCES}

Aminoff, M. J. (ed.) (1976). Spinal Angiomas, pp. 82-96. Blackwell Scientific Publications, London.

Aminoff, M. J. \& Logue, V. (1974). Clinical features of spinal vascular malformations. Brain, 94, 197-210.

Ausman, J. I., Gold, L. H., Tadavarthy, S. M., Amplatz, K. \& Chou, S. N. (I977). Intraparenchymal embolization for obliteration of an intramedullary AVM of the spinal cord. $\mathcal{F}$. Neurosurg., 47, I I9-125.

Brand, M. M. \& Bignami, A. (I969). The effects of chronic hypoxia on the neonatal and infantile brain. Brain, 92, 233-254.

Brion, S., Netsky, M. G. \& Zimmerman, H. M. (1952). Vascular malformations of the spinal cord. Arch. Neurol. and Psychiat., 68, 339-361.

Decker, R. E., Stein, H. L. \& Epstein, J. A. (I975). Complete embolization of artery of Adamkiewicz to obliterate an intramedullary arteriovenous aneurysm. Case report. F. Neurosurg., 43, 486-489.

Djindjian, R., Hurth, M. \& Houdart, R. (1970). Angiography of the Spinal Cord. Masson, Paris.

Djindjian, R., ThÉron, J. \& Merland, J. J. (1975). Embolisation of thoraco-cervical and spinal malformations and tumors. $\mathcal{F}$. Neuroradiologie, 2, 39-72.

Doppman, J. L., DiChiro, G. \& Ommaya, A. K. (1969). Selective arteriography of the spinal cord. In Modern Concepts of Radiology, Nuclear Medicine and Ultrasound, pp. I-I 57. L. E. Etter (ed.). Green, St Louis.

Doppman, J. L., DiChiro, G. \& Ommaya, A. K. (I97I). Percutaneous embolization of spinal cord arteriovenous malformations. F. Neurosurg., 34, 48-55.

Forx, C. \& Alajouanine, T. (1926). La Myélite nécrotique subaiguë. Myélite centrale angio-hypertrophique à évolution progressive, paraplégie amyotrophique lentement ascendante, d'abord spasmodique, puis flasque, s'accompagnant de dissociation albuminocytologique. Rev. Neurol., 2, I-42.

Hughes, J. T. (1976). Arteriovenous aneurysm of the spinal cord. In Greenfield's Neuropathology, pp. 680-692. W. Blackwood, J. A. N. Corsellis (eds.). Arnold, London.

Hursch, C. J., Karacan, I. \& Williams, R. L. (I972). Some characteristics of nocturnal penile tumescence in early middle-aged males. Comprehensive Psychiatry, 13, 539-548.

Hussain, A. H. \& Tozman, S. (1978). Psychiatry on Death Row. F. Clinical Psychiatry, 39, $183-888$.

KraYenbühl, H., Yasargil, M. G. \& McClintock, H. G. (1969). Treatment of spinal cord vascular malformations by surgical excision. f. Neurosurgery, 30, 427-435.

Logue, V. (I976). Practical aspects of surgical treatment. In Spinal Angiomas, pp. I3II36. M. J. Aminoff (ed.). Blackwell Scientific Publications, London.

Logue, V., Aminoff, M. J. \& Kendall, B. E. (1974). Results of surgical treatment for patients with a spinal angioma. F. Neurol. Neurosurg. Psychiat., 37, I074-I081.

MaIR, W. G. P. \& FolkerTs, J. F. (I953). Necrosis of the spinal cord due to thrombophlebitis (subacute necrotic myelitis). Brain, 76, 563-574.

Ommaya, A. K., DiChiro, G. \& Doppman, J. (I969). Ligation of arterial supply in the treatment of spinal cord arteriovenous malformations. F. Neurosurg., 30, 679-692.

Schneider, R. C., Livingston, K. E., Caev, A. J. E. \& Hamilton, G. (I965). 'Hangman's fracture' of the cervical spine. $\mathcal{F}$. Neurosurg., 22, I4I-I 54 . 